\title{
The adaptation of MAIN to Luxembourgish
}

\author{
Constanze Weth \\ University of Luxembourg
}

\section{Cyril Wealer}

University of Luxembourg

This paper describes the addition of Luxembourgish to the language versions of MAIN, the adaption process and the use of MAIN in Luxembourg. A short description of Luxembourg's multilingual society and trilingual school system as well as an overview of selected morphosyntactic and syntactic features of Luxembourgish introduce the Luxembourgish version of MAIN.

\section{Introduction}

This chapter introduces briefly the addition of Luxembourgish to the language version of the Multilingual Assessment Instrument for Narratives (LITMUS-MAIN, hereafter MAIN; Gagarina et al., 2019). It describes the adaption process and the use of MAIN in Luxembourg. Due to intensive language contact of Luxembourgish to French, productive borrowing of French lexicon into Luxembourgish as well as lexical doublets, the Luxembourgish version will widen the empirical coverage of MAIN to a multilingual setting. Although intensive contact with German also exists, the productive borrowing from German is more difficult to identify as Luxembourgish is part of the West Germanic dialect continuum.

\section{A short description of the Luxembourgish language}

Luxembourg is a small state (around 600,000 inhabitants) and bordered by France, Germany and Belgium. A distinct feature of Luxembourg is its high percentage of foreign residents. Around half of Luxembourg's population (around 322,000) has the Luxembourgish citizenship (STATEC, 2019) and only around $40 \%$ of the primary school children grow up speaking Luxembourgish at home (Lenz \& Heinz, 2018). Being a small state, Luxembourg puts forward 
strong identity-forming elements to differentiate from the neighboring countries. The Luxembourgish language and multilingualism play a central role in this policy.

Luxembourgish is a Mosel-Franconian language variety and part of the West Germanic dialect continuum. Sociolinguistically, Luxembourgish can be considered an Ausbausprache because, although an official Standard Luxembourgish with certain sociopolitical functions in Luxembourg exists, it only plays a limited role in certain official domains (Kloss, 1978). For example, children are not alphabetized in Luxembourgish but in German (see point 2.1) and the language of legislation in Luxembourg is French. Politically, Luxembourgish is the national language of the Grand Duchy of Luxembourg and acts in addition to French and German as an official language in Luxembourg. The status of Luxembourgish as a language as well as Luxembourg's official trilingual language situation were formally recognized by Luxembourgish law in 1984 (24 February, 1984 loi sur le régime des langues '1984 language law').

\subsection{Multilingualism in Luxembourg}

Multilingualism is an essential feature of the Luxembourgish society. One of its key elements is the trilingual school system (MENFP 2011; Lenz \& Bertemes, 2015). While Luxembourgish is the main language of instruction in preschool education (age 4-6), preschool children are also introduced to oral French in short playful teaching activities (e.g. singing songs, being read stories). However, although an official orthographic system exists for Luxembourgish, Luxembourgish is not the language of literacy instruction in Luxembourg. Children are formally introduced to literacy in German in Grade 1 (age 6-7) and German also constitutes the main language of instruction throughout primary school. French is added as a taught subject to the curriculum from Grade 2 (age 7-8) onwards. In addition to the trilingual school system, Luxembourg's school population is one of the most culturally and linguistically heterogeneous in Europe (OECD, 2010). The language abilities in the school languages of the children are extremely heterogeneous. The National Report of Education reports that less than $40 \%$ of fouryear-old's grow up speaking Luxembourgish, the language of preschool, at home (Lenz \& Heinz, 2018).

Although German might be present in television and picture books in Luxembourgish households, almost no pupils actively practice German (> 2\%) in family- or other non-formal education settings before they enter Grade 1 (MENJE, 2019). The largest foreign community in Luxembourg is of Portuguese nationality. Portuguese-speaking students represent around $21 \%$ of the school population in Luxembourg (MENJE, 2019).

\subsection{Linguistic characteristics}

Although Luxembourgish and German show structural overlaps, they are considered two different language systems (Gilles \& Moulin, 2003). For the adaptation of MAIN into Luxembourgish, morphosyntax and syntax as well as the lexicon are of most interest. For an overview of the phonetics of Luxembourgish, see Gilles \& Trouvain (2013). 
Luxembourgish morphosyntax overlaps largely with German Moselle Franconian dialects, but differs from Standard German (G) (Döhmer, 2017; Gilles, 2017). The following sections highlight three linguistic features of Luxembourgish that contrast to $G$ and, in some cases, are in accordance with French. The sections address aspects of morphosyntax, syntax and lexical doublets in Luxembourgish

\subsubsection{Selected aspects of morphosyntax}

As well as in $G$, nouns in Luxembourgish are categorized according to the three genders masculine, feminine and neuter. Although all three genders are productive, masculine seems to be the default gender, as most new lexical items are masculine. In addition, French loan words tend to keep their gender (Gilles, 2017).

As well as in $\mathrm{G}$, case (nominative, dative, accusative) marking is realized through articles and adjectives. The genitive case has almost disappeared and possessive constructions are expressed with dative (Döhmer, 2017). However, case is less marked than in G, as nominative and accusative overlap in general. This formal syncretism holds for all inflecting nominal word classes, except some personal pronouns.

Verbs in Luxembourgish are structurally in line with G, but inflection forms differ from G. Yet preterit has almost vanished except for the high frequency verb soen ('to say'). Instead, the present perfect is used. Except for the present tense, all verbal forms split into the inflected auxiliary and the verb, emphasizing a structure typical for Germanic varieties (Weth, 2020).

\subsubsection{Selected aspect of syntax}

The typical split verb structure in $G$ puts the inflected form at the second syntactic position in a sentence and the uninflected form at the last position. This structure is also highly productive in Luxembourgish (Ech kann dat verstoen, 'I can understand this', verbs are underlined). The inflected verb positions at the end of the sentence in subordinate clauses in German. This structure also applies to Luxembourgish, except for one specific type of subordinate clause (Döhmer, 2017; Gilles, 2017). While in the G paradigm the inflected verb shifts at the sentence's last position (...fir datt dir mech verstoe géift, ' ... so that you could understand me'), the majority of Luxembourgish speakers would produce instead ...fir datt dir mech géift verstoen. The inflected verb is underlined in the examples.

One other striking syntactic feature of Luxembourgish is the inflection of the complementizer position in dependent clauses. The conjunction takes inflectional markers for the second person singular ...fir datt $\underline{s}$ du mech géifs verstoen (Gilles, 2017).

\subsubsection{Lexical doublets in Luxembourgish}

Due to intensive language contact to French, Luxembourgish contains many loans from French, which are often integrated into Luxembourgish on phonological, orthographic and morphologic levels (Gilles, 2017). In addition, Luxembourgish allows for the alternation of lexical doublets, synonymous words from French and Luxembourgish such as Poubelle/Dreckskëscht 'bin', decidéieren/entscheeden 'to decide'. The actual choice of a French or a Luxembourgish word depends on sociolinguistic variables as well as language competence. Lexical doublets also 
exist in German. However, their detection is more difficult as Luxembourgish is part of the Germanic dialect continuum.

\section{Adapting MAIN to Luxembourgish}

This Luxembourgish version was adapted from the revised English version of the MAIN (Gagarina et al., 2019), following the guidelines for adapting MAIN to other languages (Bohnacker \& Gagarina, 2019). Together, the authors of this paper translated and adapted the protocol into Luxembourgish.

The MAIN narratives did not require any cultural adaptation. Neither the lexicon nor the syntactic structure caused any difficulties for translation. However, as doublets exist in Luxembourgish, it is useful to assess the way in which children use one or the other word form. The documentation of doublets allows for a more fine-grained analysis of Luxembourgish language use and its correlation with language biographies. In the long term, it will be interesting to observe the evolution of language use in children's narratives.

\section{The use of MAIN in Luxembourg}

A first, unpublished, version of the Luxembourgish MAIN assessing telling has been used in the research project Oral Language Development and its Predictors in Language-Minority Children from Low Income Families (Loff, 2018-2020; OLAP-C17/SC/11622484). In this project, the telling version of the Luxembourgish MAIN was used. The project investigated the role of the home language and literacy environment in the development of oral language skills in three languages (Portuguese, French and Luxembourgish) in Portuguese language-minority children (age 3-4 years) who are growing up in multilingual Luxembourg. A first publication is currently in preparation (Loff, Nikaedo, Wealer \& Leseman, in preparation).

The Luxembourgish MAIN will be piloted in the three different elicitation modes, telling, retelling and model story, at the end of the 2020.

\section{$5 \quad$ References}

Bohnacker, U. \& Gagarina, N. (2019). Background on MAIN - Revised, how to use it and adapt it to other languages. ZAS Papers in Linguistics, 63, iv-xii.

Döhmer, C. (2017). Aspekte der luxemburgischen Syntax. PhD thesis. University of Luxembourg.

Gagarina, N., Klop, D., Kunnari, S., Tantele, K., Välimaa, T., Bohnacker, U. \& Walters, J. (2019). MAIN: Multilingual Assessment Instrument for Narratives. Revised version. ZAS Papers in Linguistics, 63.

Gilles, P. (2017). Luxembourgish. Ms. University of Luxembourg. URL: https://orbilu.uni.lu/handle/10993/34559 
Gilles, P., \& Moulin, C. (2003). Luxembourgish. In A. Deumert \& W. Vandenbussche (Eds.), Germanic Standardizations. Past to present (pp. 303-329). Amsterdam: John Benjamins.

Gilles, P. \& Trouvain, J. (2013). [Illustrations of the IPA] Luxembourgish. Journal of the International Phonetic Association, 43, 67-74.

Kloss, H. (1978). Die Entwicklung neuer germanischer Kultursprachen seit 1800. Düsseldorf: Pädagogischer Verlag Schwann.

Lenz, T. \& Bertemes, J. (Eds.) (2015), Bildungsbericht Luxemburg 2015. Band 2: Analysen und Befunde. Luxembourg: Ministère de l'Education nationale, de l'Enfance et de la Jeunesse; SCRIPT; Université du Luxembourg. Retrieved from http://www.men.public.lu/catalogue-publications/themestransversaux/statistiques-analyses/bildungsbericht/2015/band-2.pdf

Lenz, T. \& Heinz, A. (2018). Das luxemburgische Schulsystem - Einblicke und Trends. In: T. Lenz, \& I. E. Baumann (Eds.). Nationaler Bildungsbericht Luxemburg 2018. Luxembourg: University of Luxembourg/SCRIPT.

Loff, A., Nikaedo C., Wealer C., Leseman, P. (in preparation). Oral Language Development and its Predictors in Language-Minority Children from Low Income Families in Luxembourg.

MENFP. (2011). Plan d'Études École Fondamentale. Luxembourg: Ministère de l'Education Nationale et de la Formation Professionnelle.

MENJE. (2019). Statistiques globales et analyses des résultats scholaires: Enseignement fondamental. Cycles 1 à 4, Année scolaire 2016/2018. Luxembourg: Ministère de l'Éducation nationale de l'Enfance et de la Jeunesse.

OECD. (2010). PISA 2009 results: Overcoming social background: Equity in learning opportunities and outcomes (Volume II). Paris: OECD Publishing.

STATEC. (2019). État de la population. Institut national de la statistique et des études économiques du GrandDuché de Luxembourg. Retrieved from: https://statistiques.public.lu/stat/TableViewer/tableView.aspx?ReportId=12853\&IF_Language=fra\&Mai nTheme $=2 \&$ FldrName $=1 \&$ RFPath $=16340 \% 2 \mathrm{c} 16341$

Weth, C. (2020). Grammatische Strukturen im mehrsprachigen Kontext sichtbar und begreifbar machen: Vorstellung des grammatikdidaktischen Materials ,Bausteine Grammatik’. In M. Langlotz (Ed.), Grammatikdidaktik - theoretische und empirische Zugänge zu sprachlicher Heterogenität (pp. 213-236). Baltmannsweiler: Schneider. 